\title{
Placement Report: Political Science Ph.D.s and ABDs on the Job Market in 1997*
}

\author{
Jun Yin, American Political Science Association
}

$t$ is of vital importance for the sustainability and growth of the discipline, and of great interest to those in the discipline, that political science doctoral students get jobs. For this reason, the American Political Science Association surveys all U.S. Ph.D.-granting political science departments regarding their placement classes' placement experiences and reports on the findings.

This is a report on the responses of 105 departments ( $81 \%$ of all Ph.D. programs) to the 1997 placement survey. It presents a picture of what the members of this placement class looked like, how they were placed, how successful they were in getting jobs, and what made them more (or less) successful candidates.

\section{Highlights of the 1997 Placement Survey}

- The number of doctoral students seeking positions in 1997 was larger than in any previous year.

- Seventy percent of the 1997 placement class found employment, a slightly higher success rate than that of the 1996 class, and similar to that of past placement classes.

- Degree status continues to be the best indicator of placement success. Job candidates with a Ph.D. did better in finding employment, and also in securing permanent positions, than did ABD candidates.

- Repeating the job search didn't seem to make much difference to placement success. While slightly more of the doctoral graduates who searched for a job in a previous year did get placed, all job seekers with a Ph.D. were almost equally successfully. Among ABDs, however, the new job seekers did better than those repeating the job search.

- Because a new "Postdoc" category was added to the 1997 questionnaire, the percentage of job candi- dates who got faculty positions in Ph.D. departments was lower in 1997 than in previous years.

- More placement candidates, including international doctoral graduates who sought employment in their own or other countries outside the U.S., were placed in non-academic positions in 1997.

- Many of the doctoral graduates were placed in temporary positions. The increase in placement in temporary positions should inform both new political scientists in their job search and career planning and Ph.D. departments in preparing their students for the changing job market.

\section{The Placement Class}

Table 1 shows that the 1997 placement class-the doctoral students seeking positions to begin in the 1997-98 academic year-was larger than any in previous years; 1112 political science doctoral graduates were on the job market during the 1996-97 academic year, a 13\% increase from 1996. The fact that slightly more departments responded to the survey in 1997 than 1996 may account for part of this reported increase, but the current response rate is comparable to that of the early $1990 \mathrm{~s}$. The 105 departments responding to the survey reported a wide range in the number of doctoral candidates seeking positions, ranging from one to 55. The mean number of job candidates from each responding department was 11 .

In 1997 , nearly half of the placement class (46\%) was repeating the job search. The same was true of the 1996 class, in which $46 \%$ were on the job market for at least the second year. The high percentage of candidates looking for employment in more than one year, the result of an ever-tightening job market, has contributed to the increasing size of placement classes. The proportion of
Ph.D.s in the 1997 placement class $(58 \%)$ was comparable to that of placement classes in the 1990s, but was lower than that of placement classes in the 1980 s (between $64 \%$ and $76 \%$ for each year). The percentage of women in the 1997 placement class (28\%) was comparable to the percentage of women searching for jobs in recent years and the percentage of women among all doctorate recipients in political science and government $(30 \%)$ reported by National Research Council (1998, 67). Such percentages are higher than the percentage of women among the doctorate recipients in economics $(22 \%)$ but lower than history (41\%), sociology (53\%), and psychology (66\%) (NRC 1998, 97).

The demographic profile of the 1997 placement class (see Table 2) resembles that of the 1996 class (Mann 1997, 603). The international component of political science job candidates is notable. Non-U.S. citizens from 41 countries comprised $14 \%$ of the placement class (see Appendix 1 for country of origin of non-U.S. placement candidates). About two-thirds of the non-U.S. citizens hold temporary visas. The proportion of non-citizens who are permanent U.S. residents increased from $23 \%$ in 1996 to $28 \%$ in 1997. Among U.S. citizens, the percentage of minority job candidates is nearly the same as in the 1996 survey. The percentage of women in the placement class remained constant $(28 \%)$. The distribution of major fields for the job candidates is also comparable to that of the 1996 class. The largest percentage of placement candidates specialized in American Government, with comparative politics second and international relations third. Similar to 1996, non-U.S. citizens tended to specialize in different fields from U.S. citizens. Forty-nine percent of the non-U.S. citizens specialized in comparative politics, $28 \%$ specialized in interna- 
TABLE 1

\section{Trends in Placement}

\begin{tabular}{lrrrrrrr}
\hline & $1997^{\star}$ & 1996 & 1995 & 1994 & 1992 & 1990 & 1988 \\
\hline Number of job candidates & 1112 & 984 & 799 & 1037 & 763 & 823 & 740 \\
\% Repeats & 46 & 46 & 41 & 40 & 33 & 32 & 32 \\
\% Ph.D. & 58 & 57 & 56 & 59 & 59 & 59 & 64 \\
\% Women & 28 & 29 & 28 & 27 & 30 & 26 & 25 \\
\hline
\end{tabular}

*1997 figures are from 105 departments (81\% of all Ph.D. programs, 86\% of programs awarding more than an average of three Ph.D.s annually, and $94 \%$ of programs awarding more than an average of eight Ph.D.s annually). In 1996, 96 departments responded (76\%), 95 departments responded in 1995 (73\%), 106 departments in 1994 (81\%), 110 departments in 1992 (87\%), 118 departments in 1990 (93\%), and 115 departments in 1988 (92\%).

** Since the large programs have been routinely included among the respondents, weighting for missing case is not necessary.

\section{TABLE 2.}

\section{Profile of 1997 Placement Class $(N=1112)$}

\begin{tabular}{|c|c|c|c|c|}
\hline Citizenship & U.S. Citizens & $953(86 \%)$ & Non-U.S. Citizens & $159(14 \%)$ \\
\hline & $\begin{array}{l}\text { White } \\
\text { Minority } \\
\text { African American } \\
\text { Latino } \\
\text { Asian American } \\
\text { Native American } \\
\text { Other } \\
\text { NA }\end{array}$ & $\begin{array}{c}837(88 \%) \\
95(10 \%) \\
40(4 \%) \\
18(2 \%) \\
20(2 \%) \\
5(1 \%) \\
12(1 \%) \\
21(2 \%)\end{array}$ & $\begin{array}{l}\text { Permanent Resident } \\
\text { Non-Perm. Resident } \\
\text { NA } \\
\text { See Appendix } 1 \text { for the lis } \\
\text { of country of origin of } \\
\text { international candidates }\end{array}$ & $\begin{array}{l}45(28 \%) \\
108(68 \%) \\
6(4 \%) \\
\text { list }\end{array}$ \\
\hline Gender & Women & $310(28 \%)$ & Men & $795(72 \%)$ \\
\hline Degree & Ph.D. & $645(58 \%)$ & $A B D$ & $466(42 \%)$ \\
\hline Fields & $\begin{array}{l}\text { Amer. Govt/Public Law } \\
\text { Comparative Politics } \\
\text { International Relations } \\
\text { Political Theory }\end{array}$ & $\begin{array}{l}324(29 \%) \\
290(26 \%) \\
219(20 \%) \\
144(13 \%)\end{array}$ & $\begin{array}{l}\text { Public Policy } \\
\text { Public Administration } \\
\text { Methodology } \\
\text { Other } \\
\text { NA }\end{array}$ & $\begin{array}{r}44(4 \%) \\
33(3 \%) \\
7(1 \%) \\
19(2 \%) \\
32(3 \%)\end{array}$ \\
\hline
\end{tabular}

tional relations, and only $5 \%$ specialized in American government (see Table 3).

\section{Placement Success}

Table 4 shows that $70 \%$ of the 1997 placement class found employment, a better rate than that of the 1996 class $(65 \%)$. The improvement in placement success was experienced by all types of candidates: Ph.D.s., ABDs, men, women, U.S. citizens, non-U.S. citizens, repeating job seekers, and new job seekers.

Who are the $70 \%$ of the graduates who found jobs? Data for the 1997 survey suggest that Ph.D.s, women, minorities, and candidates who are U.S. citizens had great placement success overall.

Degree status continues to be the best indicator of placement success. The gap in placement success between Ph.D.s (81\%) and ABDs $(53 \%)$ remained the same as for the 1996 class. This difference persisted for each demographic subgroup (see Table 5). The largest gap in placement success between Ph.D.s and ABDs was for Asian-American doctoral graduates. While $100 \%$ of the 14 Asian-American Ph.D.s were placed, only two of the six AsianAmerican ABDs were placed. Also consistent with previous findings, $\mathrm{Ph}$.D. job candidates not only did better in finding employment overall, but also in securing permanent positions than did $\mathrm{ABD}$ placement candidates.

As in 1996, women had a slightly higher rate of placement success: $73 \%$ of women and $68 \%$ of men were placed in 1997 . Women were again more successful than men in finding permanent positions, albeit by a slightly smaller margin than 1996. The gender gap in success rate was, however, much less remarkable than the gap attributable to degree status. Controlling for degree status, the difference in placement success between Ph.D. men and Ph.D. women ( $80 \%$ and $84 \%$, respectively) is much smaller than the difference in placement success between $\mathrm{ABD}$ men and $\mathrm{ABD}$ women (49\% and $60 \%$ ).

Table 5 shows that the placement success rates of African Americans, Latinos, and Asian Americans in $1997(73 \%, 72 \%$, and $80 \%)$ were generally comparable to their respective rates in $1996,(77 \%, 74 \%$, and $83 \%$ ) and were higher than that of whites $(70 \%)$. Consistent with the previous year, the overall placement success rate of non-U.S. citizens in the 1997 class $(65 \%)$ was lower than that of U.S. citizens (70\%). However, the non-U.S. doctoral graduates in the 1997 class did better in finding employment than the nonU.S. graduates in the 1996 class, due largely to the improved placement record of male international students (64\%, up from 55\%). While a considerable proportion of non-U.S. citizens found employment outside 
TABLE 4

Placement Success (\%)*

\begin{tabular}{lccccccc}
\hline & 1997 & 1996 & 1995 & 1994 & 1992 & 1990 & 1988 \\
\hline Overall & 70 & 65 & 72 & 69 & 74 & 72 & 69 \\
Ph.D. & 81 & 77 & 85 & 82 & 79 & 78 & 83 \\
ABD & 53 & 49 & 56 & 50 & 66 & 63 & 53 \\
Men & 68 & 62 & 72 & 67 & 73 & 73 & 70 \\
Women & 73 & 70 & 71 & 74 & 75 & 70 & 67 \\
Placed in Temporary Positions & 33 & 29 & 34 & 29 & 32 & 21 & 38 \\
$\quad$ Men & 33 & 30 & 36 & 29 & 34 & NA & 38 \\
Women & 32 & 26 & 31 & 29 & 28 & NA & 33 \\
\hline
\end{tabular}

*Placement success measures number placed within each category as a percentage of the total candidates within the respective category.

the United States, the percentage of non-U.S. graduates placed in permanent or temporary positions in the U.S., while still lower compared to that of the U.S. graduates, also increased from the previous year.

Whether political science graduates had been on the job market. before did not make much difference to their placement success in 1997. Table 6 shows that while slightly more of all placement candidates who searched for a job before did get placed than those who were new on the market $73 \%$ and $69 \%$, respectively), among Ph.D.s the new job seekers were almost equally successful as the candidates who repeated the job search $(81 \%$ and 83\%). Among ABD candidates, those seeking employment for the first time had a higher success rate than did those repeating their job search $(57 \%$ and $52 \%)$. Regardless of degree status, more first-time job seekers were placed in permanent positions than were candidates who were repeating their job search. These results suggest that "getting on the market early and repeating the job search" may not be a good strategy, especially for those seeking permanent employment.

\section{Placement by Fields and Hiring Institutions}

Table 7 shows that candidates' placement success varies according to their fields of specialization. Larger proportions of the candidates specializing in public policy and public administration were placed than candidates specializing in other fields in recent years, especially since 1994. In 1997, graduates in public policy continued to have the greatest success rate $(80 \%)$, followed by graduates in public administration (76\%), American government $(73 \%)$, political theory $(71 \%)$, comparative politics $(70 \%)$, international relations $(63 \%)$, and methodology $(43 \%)$. Graduates in the fields of political theory and comparative politics had a higher rate of placement success in 1997 than their counterparts in $1996(60 \%$ and 57\%, respectively).

The striking decline in the placement success rates of methodologists since the 1990 s is puzzling, especially considering the importance both job seekers and doctoral departments place on quantitative skills/methodology training (see Table 12 and Mann 1998). The downturn in placement success for methodologists will be explored in future placement surveys.

The distribution of jobs according to the field of specialization in 1997 was generally comparable to that in 1996. Candidates in American politics continued to account for the largest portion of successful candidates, followed by those in comparative politics and international relations, which is not surprising since these are the most comprehensive subfields of the discipline (see Table 8). However, such an overall distribution may not apply to international candidates or distinct racial/ ethnic groups among U.S. candidates (see Table 5). Among the nonU.S. citizens, more than half of those placed specialized in compara- tive politics and a quarter of those placed were international relations specialists. Most of the AfricanAmerican doctoral graduates who found jobs specialized in American government $(59 \%)$. In contrast, $54 \%$ of the placed Latinos, and $44 \%$ of the placed Asian Americans, specialized in comparative politics.

The data on placement by the type of hiring institutions for 1997 (see Table 9) differ from that of previous years with respect to the percentage of doctoral graduates placed in Ph.D. departments. The decline in the percentage of job candidates placed in Ph.D. departments in 1997 is largely attributable to the addition of a new "Postdoc" category to the 1997 questionnaire and the 9\% of respondents who were coded as "NA"s, meaning the type of hiring institutions was not reported or reported as unknown (such a percentage was negligible in previous years). Since there was no separate category for postdoctorate placement on past questionnaires, perhaps postdocs were reported as placement in Ph.D. departments. Another, less likely, explanation is that there has been a sudden increase in postgraduate fellowships.

The percentage of candidates placed in M.A. departments in 1997 dropped slightly from that in 1996 (from $16 \%$ to $14 \%$ ). The percentage of candidates placed in undergraduate departments in 1997 was comparable to that in previous years, accounting for around three out of ten of the placements. The proportion of non-academic placements increased slightly, from $13 \%$ to $15 \%$, and these non-academic positions were taken by candidates from all fields. The nonacademic jobs taken by doctoral graduates in 1997 covered a wide array of positions including foreign service offcer, attorney, political or research consultant, survey researcher, university administrator, foundation officer, grant proposal writer, city budget director, public relations manager, and high school teacher.

There was some association between graduates' attributes and where they were placed (see Table 5). More African Americans were placed in graduate departments, and more Latinos and Asian Americans 


\section{TABLE 5}

Placement Experience of 1997 Political Science Doctoral Students by Citizenship, Gender, and Ethnicity $(\%)^{*}$

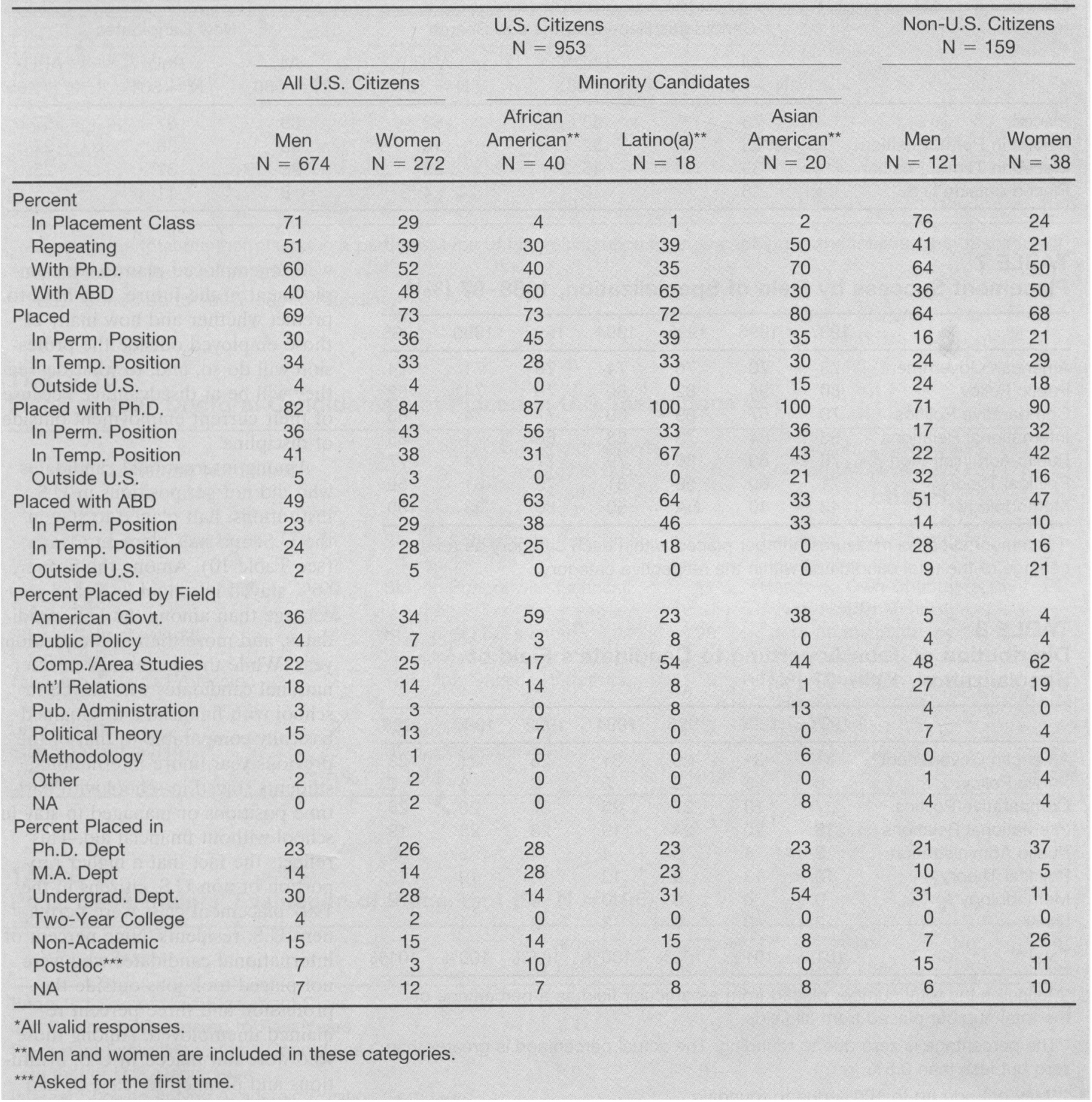

were placed in undergraduate departments, than in other types of institutions in 1997. While a comparable proportion of men and women candidates who are U.S. citizens were placed in non-academic positions, the proportion of international women candidates placed in nonacademic positions was much larger than that of international men can- didates and of U.S. citizens. A larger proportion of international women-albeit a small number-got jobs in Ph.D. departments than in other types of institutions and this proportion was larger than that of other subgroups of candidates, e.g., U.S. men, U.S. women, and international men. Also, a higher percentage of international doctoral graduates received postdoctoral fellowships than did U.S. candidates.

\section{Plans of U.S. and International Candidates Who Were Not Placed}

What did candidates do if they did not secure employment in 1997 ? 
TABLE 6

Placement Experience of 1997 Doctoral Students by Their Status of Repeating the Job Search (\%)

\begin{tabular}{|c|c|c|c|c|c|c|}
\hline & \multicolumn{3}{|c|}{ Candidates Repeating the Job Search } & \multicolumn{3}{|c|}{ New Candidates } \\
\hline & $\begin{array}{c}\text { All } \\
N=497\end{array}$ & $\begin{array}{c}\text { PhD } \\
N=333\end{array}$ & $\begin{array}{c}A B D \\
N=164\end{array}$ & $\begin{array}{c}\text { All } \\
N=586\end{array}$ & $\begin{array}{c}\text { PhD } \\
N=301\end{array}$ & $\begin{array}{c}A B D \\
N=285\end{array}$ \\
\hline Placed: & 73 & 83 & 52 & 69 & 81 & 57 \\
\hline Placed in Perm. Position & 28 & 32 & 19 & 33 & 38 & 27 \\
\hline Placed in Temp. Position & 39 & 45 & 29 & 28 & 32 & 25 \\
\hline Placed outside U.S. & 6 & 6 & 4 & 8 & 11 & 5 \\
\hline
\end{tabular}

TABLE 7

Placement Success by Field of Specialization, 1988-97 (\%)*

\begin{tabular}{lccccccr}
\hline & 1997 & 1996 & 1995 & 1994 & 1992 & 1990 & 1988 \\
\hline American Government & 73 & 70 & 76 & 74 & 78 & 71 & 74 \\
Public Policy & 80 & 94 & 82 & 80 & 78 & 74 & 82 \\
Comparative Politics & 70 & 57 & 69 & 69 & 77 & 74 & 63 \\
International Relations & 63 & 64 & 73 & 63 & 68 & 71 & 65 \\
Public Administration & 76 & 80 & 86 & 79 & 77 & 74 & 77 \\
Political Theory & 71 & 60 & 56 & 61 & 70 & 61 & 59 \\
Methodology & 43 & 40 & NA & 50 & 50 & 83 & 100 \\
\hline
\end{tabular}

*Placement success measures number placed within each category as a percentage of the total candidates within the respective category.

TABLE 8

Distribution of Jobs According to Candidate's Field of Specialization, 1988-97 (\%)*

\begin{tabular}{lrrrrrrr}
\hline & 1997 & 1996 & 1995 & 1994 & 1992 & 1990 & 1988 \\
\hline American Government & 31 & 31 & 28 & 31 & 25 & 21 & 23 \\
Public Policy & 5 & 5 & 6 & 5 & 6 & 6 & 6 \\
Comparative Politics & 27 & 23 & 27 & 25 & 27 & 28 & 26 \\
International Relations & 18 & 20 & 24 & 19 & 23 & 25 & 19 \\
Public Administration & 3 & 4 & 5 & 4 & 4 & 5 & 6 \\
Political Theory & 13 & 13 & 9 & 13 & 13 & 10 & 12 \\
Methodology $^{\star *}$ & 0 & 0 & 0 & 0 & 0 & 1 & 2 \\
Other $^{\text {Total*** }}$ & 2 & 0 & 2 & 3 & 2 & 4 & 7 \\
\hline
\end{tabular}

*Measures the total number placed from a particular field as a percentage of the total number placed from all fields.

${ }^{*}$ The percentage is zero due to rounding. The actual percentage is greater than zero but less than $0.5 \%$.

***May not add up to $100 \%$ due to rounding.

Table 10 shows that $55 \%$ of the U.S. candidates who were not placed in 1997 stayed in school, mostly in part-time jobs or with financial aid. Nine percent of the U.S. candidates who were not placed were unemployed. Fourteen percent of the U.S. candidates who did not secure a position in political science took jobs outside the profession, such as in a computer business, managing a stereo equipment store, and doing landscape design. This is somewhat worrisome because these jobs are totally unrelated to political science and have little to do with graduate training. While political science graduates who stayed in school or were unemployed plan to seek employment in the future, it is hard to predict whether and how many of those employed outside the profession will do so, and, to what degree they will be at disadvantage because of their current employment outside of discipline.

Among international candidates who did not get positions in U.S. institutions, half planed to stay in the U.S. and half planed to leave (see Table 10). Among the former, $66 \%$ stayed in school, a higher percentage than among the U.S. candidates, and more than in the previous year. While the percentage of international candidates who stayed in school with financial aid remained basically comparable to that of the previous year, more international students stayed in school with parttime positions or managed to stay in school without financial aid. This reflects the fact that a higher proportion of non-U.S. citizens in the 1997 placement class were permanent U.S. residents. Nine percent of international candidates who were not placed took jobs outside the profession and three percent remained unemployed. Among those who were not placed in U.S. institutions and planned to leave or had left the U.S., $41 \%$ found academic jobs in their own or other countries, a smaller proportion than in 1996 (64\%); $24 \%$ found non-academic jobs in their own or other countries (9\% in 1996), and 6\% were unemployed abroad (4\% in 1996). The competition for academic positions seems to be increasing overseas as well.

In the placement survey, the departments were asked whether their 
Placement by Type of Hiring Institutions, 1988-97 (\%)*

\begin{tabular}{|c|c|c|c|c|c|c|c|}
\hline & 1997 & 1996 & 1995 & 1994 & 1992 & 1990 & 1988 \\
\hline Ph.D. Department & 24 & 40 & 39 & 42 & 45 & 41 & 40 \\
\hline M.A. Department & 14 & 16 & 16 & 14 & 11 & 16 & 17 \\
\hline Undergrad. Department & 29 & 29 & 30 & 31 & 31 & 32 & 33 \\
\hline Two Year College & 3 & 2 & 2 & 2 & 2 & 2 & 2 \\
\hline Non Academic & 15 & 13 & 13 & 11 & 10 & 10 & 8 \\
\hline Post Doc ${ }^{\star \star}$ & 6 & - & - & - & - & - & 一 \\
\hline NA & 9 & - & - & - & - & - & - \\
\hline Total $^{\star \star \star}$ & $100 \%$ & $100 \%$ & $100 \%$ & $100 \%$ & $99 \%$ & $101 \%$ & $100 \%$ \\
\hline
\end{tabular}

*Measures the total number placed in a particular type of hiring institution as a percentage of the total number placed.

${ }^{\star *}$ Asked for the first time in 1997.

${ }^{\star \star \star}$ May not add up to $100 \%$ due to rounding.

\section{TABLE 10}

\section{Plans of 1997 Doctoral Candidates Not Placed in U.S. Institutions (\%)}

\begin{tabular}{|c|c|c|c|c|c|}
\hline \multicolumn{2}{|c|}{$\begin{array}{l}\text { U.S. Candidates Not Placed } \\
\qquad N=249\end{array}$} & \multicolumn{2}{|c|}{$\begin{array}{l}\text { Non-U.S. Candidates Who } \\
\text { Plan to Stay in U.S. } \\
\qquad \mathrm{N}=35\end{array}$} & \multicolumn{2}{|c|}{$\begin{array}{l}\text { Non-U.S. Candidates Who } \\
\text { Plan to Leave/Have Left U.S. } \\
\qquad N=34\end{array}$} \\
\hline $\begin{array}{l}\text { Stay in School with Financial } \\
\text { Aid }\end{array}$ & 20 & $\begin{array}{l}\text { Stay in School with Financial } \\
\text { Aid }\end{array}$ & 17 & $\begin{array}{l}\text { Return to Own Country for } \\
\text { Non-Academic Job }\end{array}$ & 21 \\
\hline Take Job Outside Profession & 14 & Take Job Outside Profession & 9 & $\begin{array}{l}\text { Go to Another Country for } \\
\text { Non Academic Job }\end{array}$ & 3 \\
\hline Unemployed & 9 & Unemployed & 3 & Unemployed & 6 \\
\hline Status Uncertain/NA & 23 & Status Uncertain/NA & 23 & Status Uncertain/NA & 29 \\
\hline Total & $\overline{101} \%$ & Total & $\overline{101} \%$ & Total & $\overline{100 \%}$ \\
\hline
\end{tabular}

\section{TABLE 11}

Ph.D. Departments' Evaluation of Placement (\%, N = 105)

\begin{tabular}{|c|c|c|c|c|c|}
\hline & $\begin{array}{l}\text { Larger } \\
\text { or Better }\end{array}$ & $\begin{array}{l}\text { About } \\
\text { the Same }\end{array}$ & $\begin{array}{l}\text { Smaller } \\
\text { or Worse }\end{array}$ & $\begin{array}{l}\text { Not } \\
\text { Sure }\end{array}$ & NA \\
\hline Expected Size of Next Placement Class & 22 & 59 & 9 & 5 & 5 \\
\hline Job Prospects Compared to Past Years & 14 & 55 & 20 & 4 & 7 \\
\hline $\begin{array}{l}\text { Placement Experience of Int'I Candidates Compared } \\
\text { to that of U.S. Candidates }\end{array}$ & 9 & 31 & 15 & 13 & 32 \\
\hline $\begin{array}{l}\text { Interest Showed in Non Academic Position Compared } \\
\text { to Past Years }\end{array}$ & 18 & 59 & 8 & 8 & 7 \\
\hline
\end{tabular}

graduate students were showing a greater interest in taking non-academic positions in government, industry, research, or other applied settings compared to students in previous years. While more departments responded positively to this question in the 1997 placement survey $(18 \%$ of the 105 departments) than in the 1996 survey (13\% of the 96 departments), fewer than one-fifth of the departments reported taking steps to prepare or help graduates look for non-academic careers (see Table 11).

\section{Job Prospects, Challenges, and Departmental Responses}

The increase in overall placement success for this year's job seekers conforms with the prediction made in the 1997 placement report that 
job prospects would be somewhat better than for the 1995-96 class (Mann 1997, 608-09). Job listings in APSA's Personnel Service Newsletter increased from 720 in 1996-97 to 806 in 1997-98 (see Appendix 2). Slightly fewer departments expected the size of their 1998 placement classes to be larger in 1997 (22\% of the 105 departments) than in the 1996 survey ( $25 \%$ of the 96 depart-
1997 job seekers than by 1996 job seekers.

While the overall placement success rate increased from $65 \%$ to $70 \%$, this was due largely to more candidates getting hired in temporary positions. The proportion of job candidates employed in temporary positions increased from $29 \%$ in 1996 to $33 \%$ in 1997, while the proportion of those receiving perma- with temporary positions in higher education (Wilson 1998) are borne out, political science graduate advisors and Ph.D. students need to be prepared for the new higher education job market and be prepared to consider non-faculty positions.

Facing such a changing market, many departments are reporting changes in their programs designed to help make their graduates em-

\section{TABLE 12}

Changes Being Made in Doctoral Programs to Help Graduates Find Jobs (\%)*

Number of responses $=82$

Increasing teacher training and teaching experience

Providing research training and opportunities

Promoting publications and conference presentations

Changing subfields and curriculum

Strengthening quantitative skills/methodology training and requirements

Modification of requirements to shorten time to degree

Reducing size of doctoral program and increasing funding for students in the program

Increasing placement support, e.g., more information on careers and job market,

workshops/forums on professional skills and job search strategy, practice job talks, department

posting job openings, helping students develop homepages and post chapters of dissertation to

the web, faculty making contacts for students, reaching out to prospective employers

Introducing and encouraging the acceptance of non-academic jobs

*52 departments responded that changes are being made, 44 departments responded that changes are not being made, and 9 departments did not respond to this question.

\section{APPENDIX 1}

\section{Country of Origin of all Non-U.S. Placement Candidates}

$(\mathrm{N}=159 ;$ Countries $=41)$

\begin{tabular}{lr}
\hline Korea & 25 \\
China & 20 \\
India & 12 \\
Britain & 8 \\
Canada & 7 \\
Turkey & 6 \\
Mexico, Germany, Iran & $5^{*}$ \\
Japan, Brazil & $4^{*}$ \\
Poland, Russia, Taiwan, Algeria, Ghana, Greece & $3^{*}$ \\
Saudi Arabia, Australia, France, Malaysia, Philippines, & \\
$\quad$ Sweden, Hong Kong, Argentina, Israel & $2^{*}$ \\
South Africa, Switzerland, Belgium, Italy, Lebanon, Nigeria, \\
$\quad$ Cyprus, Ethiopia, Netherlands, Pakistan, Nepal, Malagasy \\
Republic, Austria, Romania, Chile, Sudan, Palestine, \\
Indonesia, Zambia, Ecuador, Somalia, Thailand
\end{tabular}

*Same number of candidates for each country.

ments) (see Table 11). If this trend of more jobs and fewer candidates continues, the job market for the 1998 placement class may be more comparable to that experienced by nent positions remained comparable. If the growth in the number of temporary placement persists, and if the predictions of a steady replacement of tenure-track faculty by faculty ployable in 1997 . Fifty-two $(50 \%)$ of the 105 departments reported a variety of activities, ranging from increasing teacher training to providing research opportunities, and promoting publications and presentations to strengthening quantitative/ methodology training, aimed at preparing students for the more competitive academic job market (see Table 12). Other changes, like modifying requirements to shorten time to degree, reducing the size of the doctoral program, increasing placement support, and providing guidance about non-faculty positions, may assist doctoral graduates in their search for non-faculty as well as faculty positions. But Ph.D. departments and professional organizations can do more to assist graduate political science students. In a recent report on a special survey that examines the employment search and outcomes of recent Ph.D.s (funded by the National Science Foundation and coordinated by the Commission on Professionals 


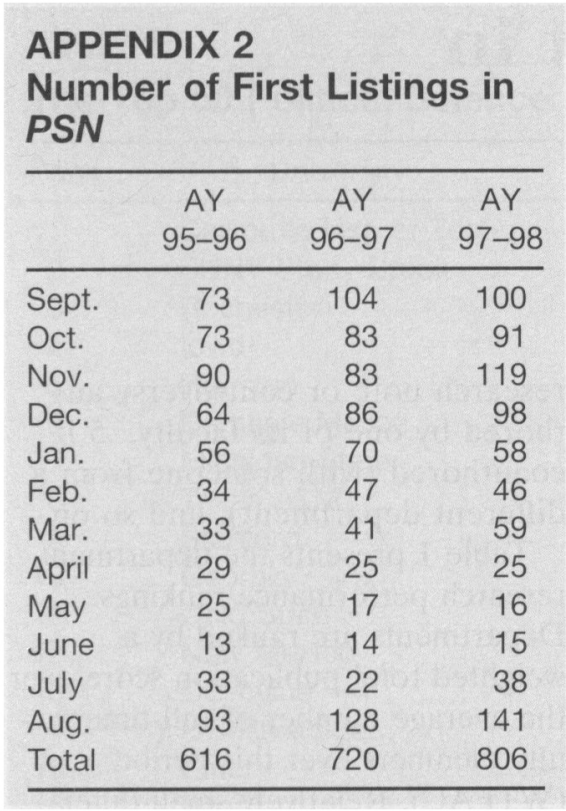

in Science and Technology), possible initiatives identified are: reducing the number of Ph.D.s, creating a professional climate supporting non-faculty careers, and increasing employment information and networks (Mann 1998, 605-07). These initiatives would be welcomed by recent political science graduates based on their own job search experiences and deserve serious consideration by Ph.D. departments.

\section{Notes}

* Data entry was made by Polly Leonard. Polly Leonard and Darren Isom assisted in preparing the tables. Sheilah Mann and Catherine Rudder suggested revisions and additions to the report.

\section{References}

Mann, Sheilah. 1997. "Placement of Political Science Doctoral Students in 1996: Degrees Matter." PS: Political Science and Politics 30(September): 60210.

-. 1998. "Finding Jobs in Political Science: 1996 Placement Candidates Report on Their Employment Search and Outcomes." PS: Political Science and Politics 31(September): 591-608.

National Research Council. 1998. Summary Report 1996: Doctorate Recipients from United States Universities. Washington, DC: National Academy Press.

Wilson, Robin. 1998. "Contracts Replace the Tenure Track for a Growing Number of Professors." The Chronicle of Higher Education, June 12. 